\title{
Release of anandamide from blood cells
}

\author{
Michael Vogeser ${ }^{1, *}$, Daniela Hauer², Shahnaz \\ Christina Azad ${ }^{2}$, Erasmus Huber ${ }^{3}$, Martin Storr ${ }^{4}$ \\ and Gustav Schelling ${ }^{2}$ \\ ${ }^{1}$ Institute of Clinical Chemistry, \\ ${ }^{2}$ Department of Anesthesiology, \\ Hospital of the University of Munich, Munich, \\ Germany \\ ${ }^{3}$ Roche Diagnostics GmbH, Penzberg, Germany \\ ${ }^{4}$ Department of Internal Medicine 2, Hospital of the \\ University of Munich, Munich, Germany
}

\begin{abstract}
Background: Endogenous ligands of cannabinoid receptors (endocannabinoids), in particular anandamide (arachidonylethanolamide), have been recognized as being of crucial importance in a variety of physiological functions. Plasma concentrations of anandamide have been measured in a number of investigations; however, discrepant data on "normal" anandamide plasma concentrations were reported. Since this might be caused by pre-analytical variables, we investigated the impact of different sample handling conditions on measured plasma anandamide concentrations.
\end{abstract}

Methods: Blood samples were taken from healthy volunteers in EDTA- or heparin-containing tubes; whole blood samples were kept at $+4^{\circ} \mathrm{C}$, room temperature, or $37^{\circ} \mathrm{C}$, respectively, for up to $120 \mathrm{~min}$ before obtaining plasma by centrifugation. Plasma anandamide concentrations were measured by an isotope-dilution liquid chromatography tandem mass spectrometry (LC-MS/MS) method.

Results: A marked time- and temperature-dependent increase in plasma anandamide concentrations ex vivo was observed in both EDTA- and heparin-containing tubes. Mean anandamide concentrations approximately doubled when EDTA samples were kept at $4^{\circ} \mathrm{C}$ for $60 \mathrm{~min}$ before centrifugation [immediately centrifuged, $1.3 \mu \mathrm{g} / \mathrm{L}$ (SD $0.3 \mu \mathrm{g} / \mathrm{L}$ ); $2.8 \mu \mathrm{g} / \mathrm{L}$ (SD $0.5 \mu \mathrm{g} / \mathrm{L}$ ) after storage for $60 \mathrm{~min} ; \mathrm{n}=12$ ). After storage of heparinized whole-blood samples for 120 min at $37^{\circ} \mathrm{C}$, a mean plasma anandamide concentration of $11.9 \mu \mathrm{g} / \mathrm{L}$ (SD $1.8 \mu \mathrm{g} / \mathrm{L}$ ) was found. In cellfree plasma, no increase in anandamide concentrations was found.

Conclusion: Anandamide is released from blood cells ex vivo at a very high rate; therefore, strictly standardized pre-analytical protocols have to be applied for plasma anandamide determination.

*Corresponding author: PD Dr. med. Michael Vogeser, Institute of Clinical Chemistry, Hospital of the University of Munich, Marchioninistr. 15, 81377 Munich, Germany Phone: + 49-89-70953221, Fax: +49-89-70953240 E-mail: michael.vogeser@med.uni-muenchen.de
Keywords: anandamide (arachidonylethanolamide); liquid chromatography-tandem mass spectrometry; preanalytical period.

\section{Introduction}

In the early 1990s, two G-protein-coupled receptors binding $\Delta$-9-tetrahydrocannabinol (THC), the major psychoactive component of marijuana, were characterized (CB1 and CB2) (1-3). Subsequently, amides and esters of long-chain polyunsaturated fatty acids have been identified as endogenous ligands of cannabinoid receptors; among these "endocannabinoids", arachidonylethanolamide (synonym anandamide) seems to be the most important (4-6).

During recent years, it has become evident that the interaction of endocannabinoids and $C B$ receptors is part of fundamental regulatory mechanisms in numerous physiological processes.

$\mathrm{CB}_{1}$ receptors have been found in most areas of the brain, generally with a presynaptic localization, where they play important roles in controlling neurotransmitter release $(7,8)$. There is strong evidence that central endocannabinoid effects are involved in cognition, pain processing, mood, memory, control of food intake and energy balance, and in problem drug use (9-11). Recently, rimonabant, a $\mathrm{CB}_{1}$ receptor antagonist, has been introduced for the treatment of drug addiction and obesity-related disorders (12).

$\mathrm{CB}_{2}$ receptors have been found primarily in peripheral locations, especially on immune and endothelial cells (3). $C_{2}$ receptor-based peripheral endocannabinoid signaling is involved in regulation of the immune system $(13-15)$, apoptosis $(16,17)$ and vasomotor activity (18-20). Recently, a link between common $\mathrm{CB}_{2}$ receptor gene polymorphisms and autoimmune diseases was suggested (21).

Endocannabinoid-inactivating enzymes, particularly fatty acid amide hydrolase (FAAH), have been proposed as therapeutic targets for a variety of diseases $(22,23)$.

Plasma concentrations of anandamide have been studied in a number of investigations (24-29); interestingly, wide variations of mean plasma anandamide concentrations were reported in cohorts of healthy volunteers [e.g., Fernandez-Rodriguez et al. (27), mean anandamide concentration $0.13 \mu \mathrm{g} / \mathrm{L}$; De Marchi et al. (24), mean concentration $0.9 \mu \mathrm{g} / \mathrm{L}$ ] (conversion of units for anandamide: $[\mathrm{nmol} / \mathrm{L}] \times 0.35 \rightarrow[\mu \mathrm{g} / \mathrm{L}]$; $[\mu \mathrm{g} / \mathrm{L}] \times 2.87 \rightarrow[\mathrm{nmol} / \mathrm{L}])$. In these studies, reliable and accurate isotope dilution mass spectrometry methods were applied, but the authors gave no detailed information on preanalytical sample handling. Since nucleated blood cells are known to be capable of both the release and metabolization of anandamide (30), preanalytical variables may account for the discrepant observations on "normal" plasma anandamide con- 
centrations. Therefore, we decided to study the impact of these variables on plasma anandamide concentrations systematically.

\section{Materials and methods}

\section{Analytical method}

For anandamide quantification, we used a novel, semi-automated, isotope-dilution liquid chromatography tandem mass spectrometry (LC-MS/MS) method. A Waters Alliance 2795 HPLC module coupled to a Waters Micromass Quattro Ultima Pt MS/MS system (Waters, Milford, MA, USA) was used. For calibration, pure solutions of anandamide in methanol/ water were used (1-50 $\mu \mathrm{g} / \mathrm{L}$ ). As an internal standard, fourfold deuterium-labeled anandamide was synthesized as previously described (31) (Figure 1); the purity of this material was $97.2 \%$.

For protein precipitation, $200 \mu \mathrm{L}$ of acetonitrile (containing $50 \mu \mathrm{g} / \mathrm{L}$ labeled anandamide) was added to $100 \mu \mathrm{L}$ of plasma. After vortex mixing and centrifugation at $16,000 \times g$ for $15 \mathrm{~min}$, a clear supernatant was obtained and transferred into HPLC vials. Aliquots of $30 \mu \mathrm{L}$ of this preparation were injected onto an extraction column (Waters Oasis HLB $^{\circledR}$ column; $25 \mu \mathrm{m}, 2.1 \times 20 \mathrm{~mm}$ ). The column was washed for $1 \mathrm{~min}$ with water/methanol $(95: 5 \mathrm{v} / \mathrm{v})$ at a flow rate of $4 \mathrm{~mL} /$ min. Using column switching with a six-port high-pressure switching valve, the extraction column was then eluted in back-flush with methanol/1 mM ammonium acetate (90:10 $\mathrm{v} / \mathrm{v}$ at $0.8 \mathrm{~mL} / \mathrm{min}$ ) and the extract was transferred onto the analytical column (LiCrospher ${ }^{\circledR} 100$ RP-18, $125 \times 4 \mathrm{~mm}$, $5 \mu \mathrm{m}$; Merck, Darmstadt, Germany) kept at $37^{\circ} \mathrm{C}$. The extraction column was subsequently washed with acetonitrile/ methanol (50:50 v/v; $1 \mathrm{~min}$ at $4 \mathrm{~mL} / \mathrm{min})$. The eluate from the analytical column was transferred at a split ratio of approximately 1:10 to the LC-MS/MS system. Electrospray atmospheric-pressure ionization in the positive mode was used. The source parameters were set to obtain the protonated quasi-molecular ions of anandamide and the labeled internal standard compound (capillary voltage, $2.3 \mathrm{kV}$; cone voltage, $50 \mathrm{~V}$; source temperature, $120^{\circ} \mathrm{C}$; desolvation temperature, $350^{\circ} \mathrm{C}$; nitrogen flow, approx. $550 \mathrm{~L} / \mathrm{h}$; collision energy, $10 \mathrm{~V}$ ). The following transitions were recorded in multiple-reaction monitoring: anandamide, $348 \rightarrow 62$; labeled anandamide, $352 \rightarrow 66$. The retention time of anandamide was approximately $5.4 \mathrm{~min}$. The method was linear from 0.8 to $50 \mu \mathrm{g} / \mathrm{L}$ and was reproducible, with inter-assay coefficients of variation of $6.8 \%$ and $5.3 \%$ for mean anandamide concentrations of 2.1 and $12.8 \mu \mathrm{g} / \mathrm{L}$, respectively $(n=12)$. No significant differences in the peak areas of deuterated anandamide were observed when pure solutions or plasma samples were spiked, ruling out relevant ion-suppression effects. The lower limit of detection of the method (defined as a signal/noise ratio $\geq 4: 1$ ) was $0.5 \mu \mathrm{g} / \mathrm{L}$. A representative chromatogram is shown in Figure 2.

\section{Experiments}

In a first study, 12 healthy volunteers were included after written informed consent. Blood was collected by venipuncture into five EDTA-containing tubes (S-Monovette ${ }^{\circledR}$ EDTA; Sarstedt, Numbrecht, Germany). One of the tubes was centrifuged within 5 min after venipuncture and plasma was immediately frozen $\left(-20^{\circ} \mathrm{C}\right)$. Two tubes were kept at $+4^{\circ} \mathrm{C}$ and were centrifuged after 60 or $120 \mathrm{~min}$, respectively, to obtain plasma, which was then frozen immediately. Two further tubes were kept at room temperature $\left(22-25^{\circ} \mathrm{C}\right)$ for 60 or $120 \mathrm{~min}$ before centrifugation.

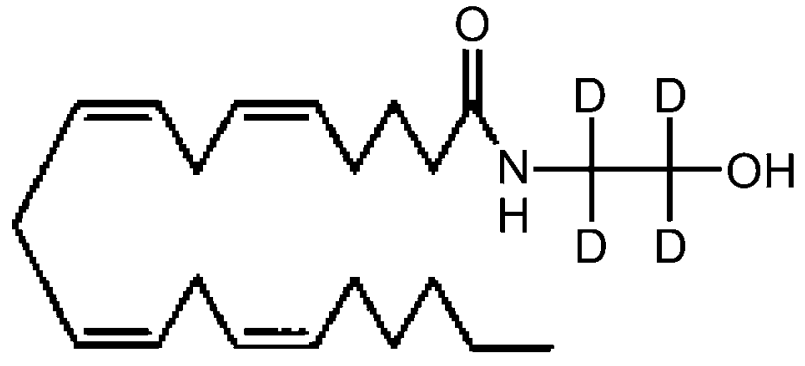

Figure 1 Chemical structure of deuterated anandamide used for internal standardization.

In plasma samples obtained immediately after venipuncture, a mean anandamide concentration of $1.3 \mu \mathrm{g} / \mathrm{L}$ was found (SD $0.3 \mu \mathrm{g} / \mathrm{L}$ ). In plasma of samples kept at $+4^{\circ} \mathrm{C}$ for 60 and $120 \mathrm{~min}$, mean concentrations of $2.8 \mu \mathrm{g} / \mathrm{L}$ (SD 0.5 $\mu \mathrm{g} / \mathrm{L}$ ) and $3.8 \mu \mathrm{g} / \mathrm{L}$ (SD $0.4 \mu \mathrm{g} / \mathrm{L}$ ), respectively, were measured ( $p<0.05$; paired Wilcoxon test). In plasma of samples kept at room temperature, mean concentrations of $3.8 \mu \mathrm{g} / \mathrm{L}$ (SD $1.0 \mu \mathrm{g} / \mathrm{L}$ ) after $60 \mathrm{~min}$ and $5.2 \mu \mathrm{g} / \mathrm{L}$ (SD $0.6 \mu \mathrm{g} / \mathrm{L}$ ) after $120 \mathrm{~min}$ were found $(\mathrm{p}<0.05)$. Thus, a significant time- and temperature-dependent increase in plasma anandamide concentrations was observed. This may be explained by the release of anandamide from circulating immune cells (19, 30).

We suspected that this release might in part be the consequence of non-physiological stimulation of leukocytes due to calcium chelation by EDTA and a temperature below $37^{\circ} \mathrm{C}$ in the sample tubes. Therefore, in a second set of experiments, we used heparin-anticoagulated whole blood samples (S-Monovette ${ }^{\circledR}$ Lithium-Heparin; Sarstedt) kept at $+4^{\circ} \mathrm{C}$, room temperature, or $37^{\circ} \mathrm{C}$ for 30,60 and $120 \mathrm{~min}$. In samples from five healthy volunteers, a time- and temperaturedependent increase in anandamide concentrations was again observed (Figure 3). The most marked increase in anandamide concentrations was found in samples stored at $37^{\circ} \mathrm{C}$; at this temperature, a mean " $\Delta$ anandamide" of 7.5 $\mu \mathrm{g} / \mathrm{L}$ (SD $1.4 \mu \mathrm{g} / \mathrm{L}$ ) was observed between 30 and $120 \mathrm{~min}$ after venipuncture. Lactate dehydrogenase (LDH), aspartate aminotransferase (AST), alanine aminotransferase (ALT), potassium, and glucose were analyzed in the plasma samples obtained immediately and after incubation at $37^{\circ} \mathrm{C}$ for $120 \mathrm{~min}$, respectively. While glucose concentrations decreased by a mean of $19 \%$, no significant changes in the concentrations of the other analytes were observed.

In a third set of experiments, whole blood samples from ten healthy volunteers were precipitated with a 4:1 mixture of methanol/zinc sulfate $50 \mathrm{~g} / \mathrm{L}$ immediately after sampling ( $200 \mu \mathrm{L}$ of whole blood and $200 \mu \mathrm{L}$ of precipitation solution); after centrifugation, supernatants were analyzed for anandamide. In all cases the anandamide signal was below the predefined lower limit of detection $(<0.5 \mu \mathrm{g} / \mathrm{L})$.

To study the stability of anandamide in cell-free plasma, aliquots of six plasma samples obtained during the incubation experiments were kept at room temperature for $24 \mathrm{~h}$ prior to analysis (concentration range $2.0-14.0 \mu \mathrm{g} / \mathrm{L}$ ). A decrease in mean anandamide concentration of $9.5 \%$ within $24 \mathrm{~h}$ was observed.

The investigation protocols for all experiments were approved by the institutional Review Board.

\section{Results and discussion}

We were able to demonstrate extensive release of anandamide from whole blood cells ex vivo. This 
9

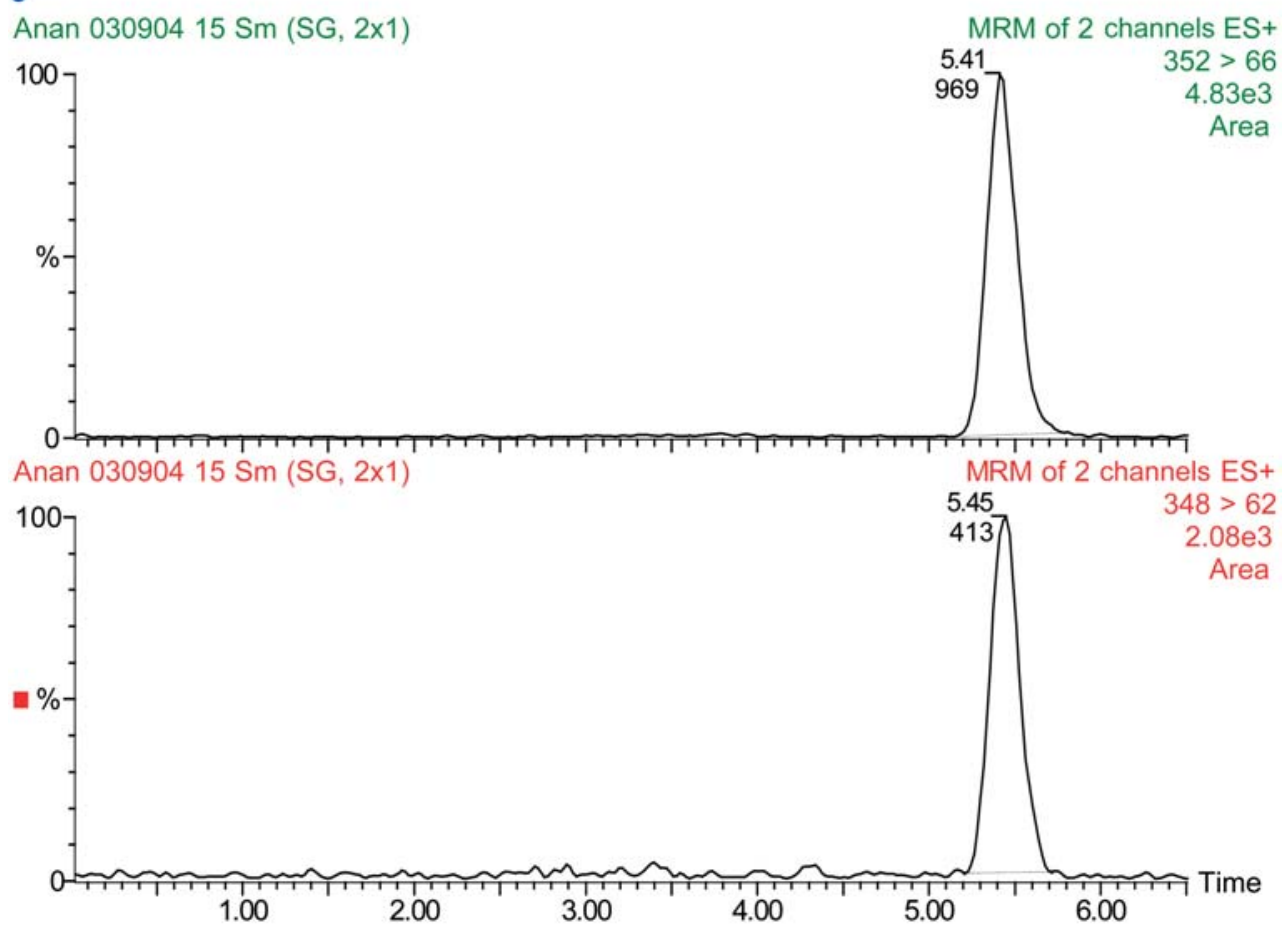

Figure 2 Representative chromatogram of anandamide and deuterated anandamide used as the internal standard obtained from a human whole-blood sample (concentration of anandamide, $4.3 \mu \mathrm{g} / \mathrm{L}$; Y-axis represents the relative intensity of the signal with respect to the baseline of the chromatogram).

release may result from mobilization of pre-existing anandamide from cellular structures of blood cells, from de novo synthesis and exocytosis of anandamide ex vivo by blood cells, or from a combination of both.

To clarify this issue, we precipitated whole blood samples by adding methanol immediately after venipuncture under the assumption that this procedure would block all metabolic processes and disintegrate cell membranes. After centrifugation, we found only trace concentrations of anandamide in the supernatant. It cannot be completely ruled out that anandamide in part undergoes co-precipitation with proteins in this experiment; however, our observation rather suggests de novo synthesis of anandamide than release of pre-existing anandamide to cause ex vivo increases in plasma anandamide concentrations.

We conclude from our results that the determination of baseline plasma anandamide concentrations has to follow strictly standardized pre-analytical protocols with immediate sample centrifugation. Even if this protocol is followed, it cannot be completely ruled out that anandamide is released into plasma during centrifugation.

Stasis, hypoxia, and the foreign surface of a sample tube may trigger anandamide synthesis and release from blood cells; the potential of leukocytes to form anandamide has been demonstrated previously (19, 30 ). The in vivo baseline rate of anandamide synthesis in these cells under physiological conditions, however, remains uncertain. Besides preanalytical considerations, our data demonstrate that blood cells actually posses a very high anandamide release capacity in response to stressful stimuli; this may be of functional relevance for the peripheral $\mathrm{CB}_{2}$ receptor-based endocannabinoid system (14-21).

Furthermore, our results demonstrate the feasibility of characterizing the anandamide release capacity of blood cells using a standardized ex vivo sequential plasma sampling protocol from incubated heparinized whole blood, providing a " $\Delta$ anandamide", e.g., between 30 and $120 \mathrm{~min}$ after venipuncture. During this time interval, we found a linear increase in anandamide concentrations in samples from healthy vol-

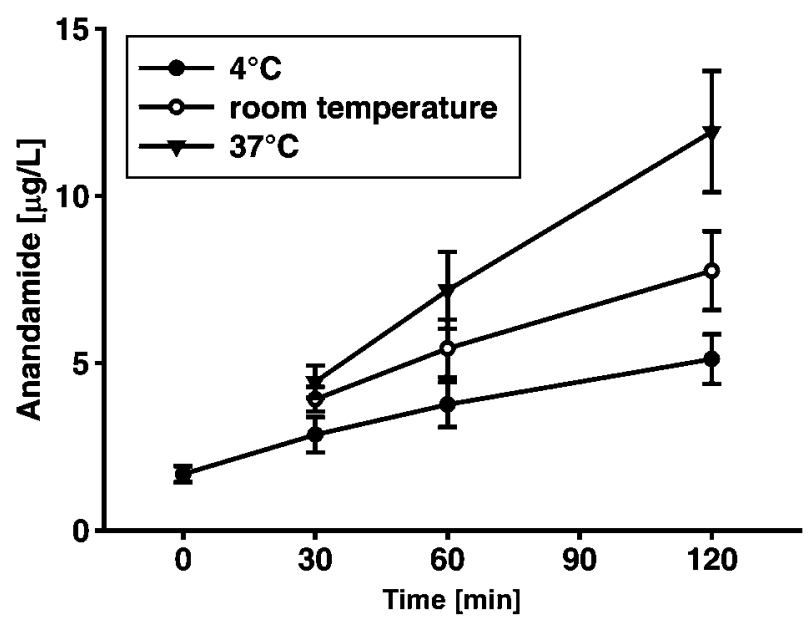

Figure 3 Anandamide concentrations found in plasma of heparinized whole-blood samples incubated at various temperatures for different time intervals (mean and SD; $n=5$ ). Conversion of units for anandamide: $[\mathrm{nmol} / \mathrm{L}] \times 0.35 \rightarrow[\mu \mathrm{g} / \mathrm{L}]$; $[\mu \mathrm{g} / \mathrm{L}] \times 2.87 \rightarrow[\mathrm{nmol} / \mathrm{L}]$. 
unteers (Figure 3). We plan to use this sampling principle in further studies to investigate blood-cell anandamide synthesis capacity in health and different disease states.

\section{References}

1. Matsuda LA, Lolait SJ, Brownstein MJ, Young AC, Bonner TI. Structure of a cannabinoid receptor and functional expression of the cloned cDNA. Nature 1990;346: 561-4.

2. Munro S, Thomas KL, Abu-Shaar M. Molecular characterization of a peripheral receptor for cannabinoids. Nature 1993;365:61-5.

3. Di Marzo, De Petrocellis VL, Fezza F, Ligresti A, Bisogno T. Anandamide receptors. Prostaglandins Leukot Essent Fatty Acids 2002;66:377-91.

4. Devane WA, Hanus L, Breuer A, Pertwee RG, Stevenson LA, Griffin G, et al. Isolation and structure of a brain constituent that binds to the cannabinoid receptor. Science 1992;258:1946-9.

5. Di Marzo V, Deutsch DG. Biochemistry of the endogenous ligands of cannabinoid receptors. Neurobiol Dis 1998;5:386-404.

6. Sugiura T, Waku K. Cannabinoid receptors and their endogenous ligands. J Biochem 2002;132:7-12.

7. Pertwee RG, Ross RA. Cannabinoid receptors and their ligands. Prostaglandins Leukot Essent Fatty Acids 2002; 66:101-21.

8. Freund TF, Katona I, Piomelli D. Role of endogenous cannabinoids in synaptic signaling. Physiol Rev 2003;83: 1017-66.

9. Walker JM, Huang SM. Endocannabinoids in pain modulation. Prostaglandins Leukot Essent Fatty Acids 2002; 66:235-42.

10. Chiang KP, Gerber AL, Sipe JC, Cravatt BF. Reduced cellular expression and activity of the P129T mutant of human fatty acid amide hydrolase: evidence for a link between defects in the endocannabinoid system and problem drug use. Hum Mol Genet 2004;13:2113-9.

11. Di Marzo V, Matias I. Endocannabinoid control of food intake and energy balance. Nat Neurosci 2005;8:585-9.

12. Despres JP, Golay A, Sjostrom L, Rimonabant in Obesity-Lipids Study Group. Effects of rimonabant on metabolic risk factors in overweight patients with dyslipidemia. N Engl J Med 2005;353:2121-34.

13. Klein TW, Lane B, Newton CA, Friedman H. The cannabinoid system and cytokine network. Proc Soc Exp Biol Med 2000;225:1-8.

14. Parolaro D, Massi $P$, Rubino T, Monti E. Endocannabinoids in the immune system and cancer. Prostaglandins Leukot Essent Fatty Acids 2002;66:319-32.

15. Klein TW, Newton C, Larsen K, Lu L, Perkins I, Nong L, et al. The cannabinoid system and immune modulation. J Leukoc Biol 2003;74:486-96.

16. Maccarrone M, Finazzi-Agro A. The endocannabinoid system, anandamide and the regulation of mammalian cell apoptosis. Cell Death Differ 2003;10:946-55.

17. Yamaji K, Sarker KP, Kawahara K, lino S, Yamakuchi M, Abeyama $\mathrm{K}$, et al. Anandamide induces apoptosis in human endothelial cells: its regulation system and clinical implications. Thromb Haemost 2003;89:875-84.

18. Randall MD, Kendall DA. Endocannabinoids: a new class of vasoactive substances. Trends Pharmacol Sci 1998; 19:55-8.

19. Wagner JA, Hu K, Bauersachs J, Karcher J, Wiesler M, Goparaju SK, et al. Endogenous cannabinoids mediate hypotension after experimental myocardial infarction. J Am Coll Cardiol 2001;38:2048-54.

20. Wagner JA, Jarai Z, Batkai S, Kunos G. Hemodynamic effects of cannabinoids: coronary and cerebral vasodilation mediated by cannabinoid $\mathrm{CB}(1)$ receptors. Eur $\mathrm{J}$ Pharmacol 2001;423:203-10.

21. Sipe JC, Arbour N, Gerber A, Beutler E. Reduced endocannabinoid immune modulation by a common cannabinoid 2 (CB2) receptor gene polymorphism: possible risk for autoimmune disorders. J Leukoc Biol 2005; 78:231-8.

22. Cravatt BF, Giang DK, Mayfield SP, Boger DL, Lerner RA, Gilula NB. Molecular characterization of an enzyme that degrades neuromodulatory fatty-acid amides. Nature 1996:384:83-7.

23. Cravatt BF, Lichtman AH. Fatty acid amide hydrolase: an emerging therapeutic target in the endocannabinoid system. Curr Opin Chem Biol 2003;7:469-75.

24. De Marchi N, De Petrocellis L, Orlando P, Daniele F, Fezza $F$, Di Marzo V. Endocannabinoid signalling in the blood of patients with schizophrenia. Lipids Health Dis 2003;2:5.

25. Obata T, Sakurai $Y$, Kase $Y$, Tanifuji $Y$, Horiguchi T. Simultaneous determination of endocannabinoids (arachidonylethanolamide and 2-arachidonylglycerol) and isoprostane (8-epiprostaglandin F2alpha) by gas chromatography-mass spectrometry-selected ion monitoring for medical samples. J Chromatogr B Analyt Technol Biomed Life Sci 2003;792:131-40.

26. Sparling PB, Giuffrida A, Piomelli D, Rosskopf L, Dietrich A. Exercise activates the endocannabinoid system. Neuroreport 2003;14:2209-11.

27. Fernandez-Rodriguez CM, Romero J, Petros TJ, Bradshaw $\mathrm{H}$, Gasalla JM, Gutierrez ML, et al. Circulating endogenous cannabinoid anandamide and portal, systemic and renal hemodynamics in cirrhosis. Liver Int $2004 ; 24: 477-83$.

28. Giuffrida A, Leweke FM, Gerth CW, Schreiber D, Koethe D, Faulhaber J, et al. Cerebrospinal anandamide levels are elevated in acute schizophrenia and are inversely correlated with psychotic symptoms. Neuropsychopharmacology 2004;29:2108-14.

29. Habayeb OM, Taylor AH, Evans MD, Cooke MS, Taylor DJ, Bell SC, et al. Plasma levels of the endocannabinoid anandamide in women - a potential role in pregnancy maintenance and labor? J Clin Endocrinol Metab 2004; 89:5482-7.

30. Bisogno T, Maurelli S, Melck D, De Petrocellis L, Di Marzo V. Biosynthesis, uptake, and degradation of anandamide and palmitoylethanolamide in leukocytes. J Biol Chem 1997;272:3315-23.

31. Giuffrida AF, Piomelli D. Isotope dilution GC/MS determination of anandamide and other fatty acylethanolamides in rat blood plasma. FEBS Lett 1998;422:373-6.

Received September 5, 2005, accepted January 3, 2006 